\title{
ЭЛЕКТРОПОЛИМЕРИЗАЦИЯ НОВЫХ ФОРМ ФЕНОТИАЗИНОВ И ИХ ПРИМЕНЕНИЕ В ДНК-СЕНСОРАХ
}

Куликова Т.Н., Маланина А.Н., Падня П.Л., Евтюгин Г.А. Казанский (Приволжский) федеральный университет, Казань, Россия wefy2009@yandex.ru

DOI: 10.26902/ASFE-11_116

Фенотиазины как медиаторы электронного переноса находят широкое применение в биосенсорике, в том числе в электрохимических ДНК-сенсорах для определения лекарственных препаратов по их взаимодействию с ДНК. Электрополимеризация фенотиазинов расширяет возможности их включения в состав биосенсоров благодаря легкости получения, возможности контроля толщины и свойств образующегося покрытия. Электрохимические свойства полимерных форм замещенных фенотиазинов зависят от распределения зарядов в слое, даже их незначительное изменение проявляется в соответствующих сдвигах потенциалов и токов пика на вольтамперограммах [1]. В данной работе, нами проведена электрополимеризация N-фенил-3-(фенилимино)-3Н-фенотиазин-7амина (рис. 1) и исследовано его поведение в составе ДНК-сенсора.<smiles>c1ccc(N=c2ccc3nc4ccc(Nc5ccccc5)cc4sc-3c2)cc1</smiles>

Рис.1 Химическая структура восстановленной мономерной формы N-фенил-3(фенилимино)-3Н-фенотиазин-7-амина

Полимеризацию проводили из смеси серной кислоты и ацетона с последующей инкубацией электрода в водном растворе ДНК, предварительно насыщенной Метиленовым синим. Поскольку Метиленовый синий и доксорубицин участвуют в конкурентных взаимодействиях с одними и теми же участками ДНК, предварительное введение Метиленового синего увеличивает чувствительность сигналов на вольтамперограммах к процессам интеркалирования ДНК [2]. Разработанный ДНК-сенсор проявил чувствительность к доксорубицину на уровне его концентраций в диапазоне 0.05 - 10 нМ.

Для импедиметрической регистрации сигнала ДНК сенсора предложено ввести в состав продукта полимеризации карбоксилатное производное тиакаликс[4]арена. Наибольшее влияние на электрохимические свойства получаемого покрытия при сохранении эффективности электрополимеризации оказывало включение в состав слоя тиакаликс[4]арена в конфигурации альтернат, его аналоги в конфигурации конус и частичныий конус не влияли на электрохимическую активность, но снижали выход продукта полимеризации. Изменение в характеристиках полимеризации и влиянии макроциклов обусловлено стерическими факторами, определяющими взаимодействие катионных центров продукта полимеризации и карбоксилатных групп макроцикла. Дальнейшее инкубирование сенсора в водном растворе 1 мг/мл ДНК из молок лосося позволили получить устойчивое покрытие, характеристики сопротивления заряда которого менялись в присутствии доксорубицина как модельного интеркалятора ДНК. Биосенсор позволял проводить определение доксорубицина в интервале концентраций от 0.1 до 5 нМ.

Список литературы

1. Yu. Kuzin, P. Padnya, I. Stoikov, G. Evtugyn, D. Stoikov, V. Gorbatchuk, A. Khadieva. Electrochim. Acta 345

(2020) 136195

2. T. Kulikova, A. Porfireva, R. Shamagsumova, G. Evtugyn. Electroanal. 30 (2018) 2284

Исследования проводились в рамках РНФ 19-73-10134. 